\title{
Implementation of Integrated Marketing Communication at Kampoeng Semarang
}

\author{
$1^{\mathrm{st*}}$ Monika Teguh \\ Communication Science Department \\ Universitas Ciputra \\ Surabaya, Indonesia \\ monika.teguh@ciputra.ac.id \\ $4^{\text {th }}$ Josephine Kurniawan Lukito \\ Communication Science Department \\ Universitas Ciputra \\ Surabaya, Indonesia \\ jkurniawan04@student.ciputra.ac.id
}

\author{
$2^{\text {nd }}$ Emanuelle Dea Nathalie Widjaja \\ Communication Science Department \\ Universitas Ciputra \\ Surabaya, Indonesia \\ emanuelle131297@gmail.com
}

\author{
$3^{\text {rd }}$ Louisa Christine Hartanto \\ Communication Science Department \\ Universitas Ciputra \\ Surabaya, Indonesia \\ christine.hartanto@ciputra.ac.id
}

\begin{abstract}
The very rapid development of tourism in Indonesia brings many opportunities for business development in the field of tourism. Central Java Province is one of the provinces with quite a big attraction supported by 198 commercial businesses and 57 non-commercial in the tourism sector. This provides a good opportunity for entrepreneurs to develop businesses in the field. One example is Kampoeng Semarang, which is a business that is engaged in the souvenirs sector and also offers products in the arts, crafts and culture in Semarang. Kampoeng Semarang becomes "One Stop Shopping \& Leisure" which is equipped with facilities such as souvenir centers, batik galleries, restaurants \& cafes, souvenir centers, WeBe Fashion Bags stands, household appliances, tourism information, meeting rooms, even children's galleries and playgrounds. To get a competitive advantage, Kampoeng Semarang can implement Integrated Marketing Communication (IMC). By implementing the IMC, Semarang Kampoeng has been known by local and foreign tourists. Therefore, this study was conducted to determine the Integrated Marketing Communication at Kampoeng Semarang which covers the use of marketing communication mix and integrated marketing communication. This research is a descriptive study using data collection methods namely interviews, observation and documentation. The results of this study are the determination of the IMC begins with capturing opportunities, where tourism in Semarang is in a developing condition. The company then determines the market segments $(S)$ and targets (T) and makes a positioning (P), or better known as the STP process. Then determined the marketing strategy that includes products, prices, places, and promotions, or better known as 4P. Specifically the promotion conducted by Kampoeng Semarang focuses on two target markets, namely partners and end users or tourists. The type of promotion carried out is tailored to the needs of each target market. For partners the emphasis is on providing added value if they bring consumers to Kampoeng Semarang, and establish good relations through sales promotion and direct marketing activities. As for direct consumers, promotional activities are more varied to gain awareness and encourage their purchases. There is one type of promotion given to partners and end users, namely digital marketing communication. This activity is carried out considering the two types of targets can be reached with it.
\end{abstract}

Keywords-Kampoeng Semarang, Integrated Marketing Communication, tourism

\section{INTRODUCTION}

Tourism industry in Indonesia has been growing rapidly, as reported by the Indonesia Investment's website [1]. Nowadays, this sector contributes approximately $4 \%$ to the total economy of Indonesia. Indonesian government keeps trying to improve existing infrastructure and develop existing tourism destinations. Arief Yahya, the Minister of Tourism at the time, expected that Indonesia can become one of the world's 30 best tourist places to visit globally, hence obtaining foreign exchange of the country maximally through the tourism industry [2].

One of the areas in Indonesia that becomes tourism destination is Semarang. Data showed that the number of tourists who visited Semarang regency and Semarang city in 2015 were 4.990 .020 people and generated revenues up to Rp. 34.922.396.794 (Dinas Kepemudaan Olah Raga dan Pariwisata Provinsi Jawa Tengah, 2016). The strategic location of Semarang also produces other potentials that can be maximally used for the development of its tourism industry. One of the potentials is business of souvenirs as a uniqueness of a certain tourism area. The most famous souvenirs business area in Semarang is in Pandanaran road. There are two famously known stores for their bandeng presto (milkfish high-temperature cooked milkfish) in this souvenirs center, the store under the name "Bandeng Presto yang pertama sejak tahun 1977 (the first Bandeng Presto since 1977)" and "Bandeng Juwana" [3]. Additionally, the other souvenirs center that is currently growing rapidly is Kampoeng Semarang (Semarang village) which has become a new tourism destination in Semarang in the category of shopping tourism [4].

Reporting from its official website, Kampoeng Semarang was officially opened by the Governor of Central Java in May, 2012 to become the leading "One Stop Shopping and Leisure" in Semarang. Under this tagline, Kampoeng Semarang offers various products for all tourists in Semarang to enjoy [5]. This area is equipped with many facilities from souvenirs and gift centers, batik galleries, restaurants and cafes, WeBe Fashion Bags booth, home ware, tourism information, and meeting gallery, to kids' gallery and playground. Those facilities support this 4.000 square meters area as one of tourism 
destination by offering creative work as one of the tourist destinations by offering creative work as a potential for Semarang in particular and Central Java in general [6]. Since Kampoeng Semarang sells a wide range of products from typical souvenirs from Semarang to culinary, this area needs to do various marketing strategies to make the products better known.

The developments of Kampoeng Semarang each year shows the number of visitors tends to be stable even though it experienced a decline in 2014-2016. Even so, Kampoeng Semarang continues to strive to do good marketing so that the number of visitors in 2018 has increased dramatically to almost double the previous year. Data of visitors who visited and had transactions in Kampoeng Semarang can be seen in table below:

TABLE I. TABLE 1. KAMPOENG SEMARANG VISITORS

\begin{tabular}{|c|c|}
\hline \multicolumn{2}{|c|}{$\begin{array}{c}\text { NUMBER OF KAMPOENG SEMARANG VISITORS FROM } \\
\text { 2012-2020 }\end{array}$} \\
\hline \multicolumn{1}{|c|}{ Year } & Number Of Visitors \\
\hline 2012 & 23.619 \\
\hline 2013 & 25.372 \\
\hline 2014 & 18.214 \\
\hline 2015 & 19.949 \\
\hline 2016 & 14.983 \\
\hline 2017 & 29.472 \\
\hline 2018 & 44.967 \\
\hline
\end{tabular}

This can happen because they implement Integrated Marketing Communication (IMC). The success of the IMC programs continues to show positive results. Starting from the increasing number of consumers, the use of Kampoeng Semarang location for shooting soap operas, until the arrival of national and international public figures, one of them was Matt Damon, a famous Hollywood actor as seen in figure below:

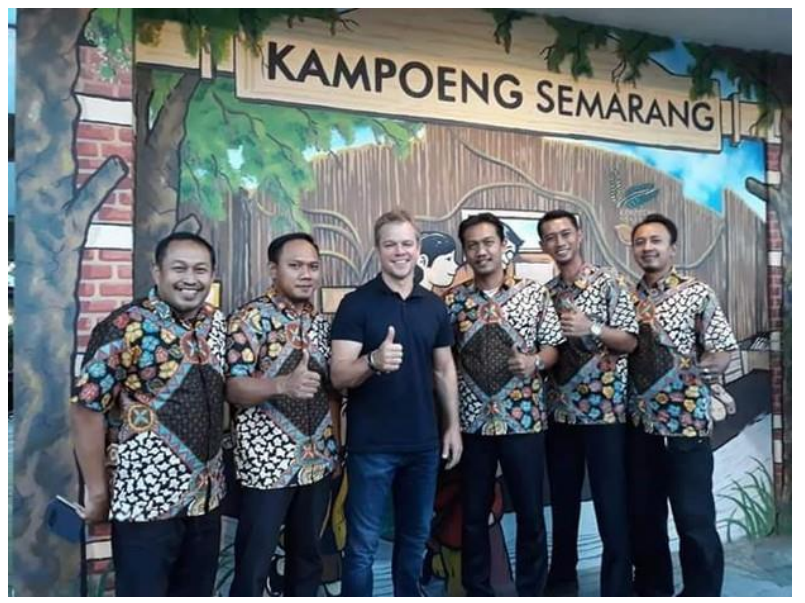

Fig. 1. Matt Damon Visited Kampoeng Semarang

Based on this background, this research will explore more deeply about the implementation of the IMC conducted by Kampoeng Semarang

\section{RESEARCH METHOD}

This research was a descriptive qualitative research. Data were obtained through interviews, observation and documentation. Interview method was chosen to understand certain problems [7]. The form of interviews conducted was a semi-structured interview or interview with open questions under certain themes and flows of conversation, time of interview could still be predicted, flexible yet controlled, and interview guidelines were available (flow, sequence and diction choices). The form of observations made was direct observation carried out by directly observing the research objects without any transparent media. In this research, the objects observed were sales activities and marketing processes Kampoeng Semarang [8]. Later, the forms of documents used in this research were both internal official documents of the company and external documents (information from newspapers, magazines or other relevant media). The data obtained were analyzed through four phases: data collection, data reduction, data display, and conclusion withdrawal [9]. The informants were selected through source triangulation technique. They consisted of one business owner in Kampoeng Semarang, one tour leader who guides visitors to Kampoeng Semarang, two consumers of Kampoeng Semarang, and one expert who is also a practitioner of tourism marketing. This triangulation technique was also conducted as a technique of data validation. Gunawan [10] explains that source triangulation is the use of two or more sources in research to obtain comprehensive picture for the phenomena being studied. Data reliability in this research was through rechecking technique, exploring various and comprehensive data, and adding research informants [11].

\section{RESULT AND DISCUSSION}

\section{A. The Integrated Marketing Communication Strategy}

Based on the results of data analysis, there has been a significant movement in the tourism industry in understanding the main components of IMC. Tourism movement initiated by the government has impact on the rapid movement of businesses in the tourism sector. The government now realizes that tourism is one of the attractions that can generate significant regional income. Business practitioners also viewed this as a good opportunity to advance their business. One of the informants, a business owner, experienced the government's support for their business. Souvenirs business is one of business sectors that most people look for when visiting a tourism area. The other informants that understand about tourism, the expert and the partner, also viewed the government's support as opportunity. Opportunity analysis is urgently needed to support the right marketing as proven by Caemmere's findings [12], that plan and implementation of complex integrated marketing communication must involve different managerial tasks such as situation analysis and opportunity identification.

When there is a big opportunity available, people will compete to seize that opportunity, so all business surely has their respective competitors. One of the informants, the business owner, has overcome competitors competently and confidently by looking at competitors as positive learning media which can encourage this informant to appear differently and innovatively in order to become more superior from this informant's competitors. The informant keeps doing self-exploration and supports the availability of product, price and place which are in line with the theory of Belch and Belch [13] that companies need to have a competitive advantage as its uniqueness which cannot be replaced or imitated by similar or substitute products or services. 
Products offered by a company must target the right market, as stated by Belch and Belch [13] that market selection is very useful for a company as an effort to set the company's focus when implementing IMC. The company will set different objectives according to the targeted market condition. In this research, since the target market of the informant is tour and travel group, the business area is adjusted to large capacity and equipped with diverse products.

The owner as informant in this research has already identified market for, he business, which is reaching all regions in Indonesia, and has already understood that potential consumers reach its maximum number when high season or during long holiday. Furthermore, consumers who have been interviewed as the informants for this research also agreed that their main reasons to visit the business center were looking for souvenirs, relaxing, and trying other facilities such as restaurants. Women of all ages and demographics were more likely to shop. In addition to that, consumers' practical lifestyle and prefer both ornaments and good packaging have become considerations for the owner. This market identification and segmentation makes these two informants, the owner and the expert, preferred concentrated marketing as their targeting strategy, meaning that they focused on certain segment which is tour and travel. Therefore, achieving the market in this chosen segment as large as possible was the right marketing to do. These steps are good enough and already in line with the theory of Belch and Belch [13] that the identification process must be made in detail, ranging from determining the width of geographical area to what needs can be fulfilled by the company, segmenting consumers according to geographical area and habits, and finally choosing the right type of marketing.

The concept of one stop leisure promoted by the owner has got positive respondents from other informants. It has become the main attraction that makes Kampoeng Semarang a shopping choice. The shifting focus to the souvenirs center was also responsively received by other informants. The concept has been embedded in the minds of four other informants and made them able to distinguish other products offered by competitors. This means that Kampoeng Semarang has done right positioning well enough. Planning the segmentation, targeting, and positioning (STP) is very influential on business development which is supported by Rismayanti's findings [14], where a business has a chance of failure if it does not apply the right STP. The concept of Kampoeng Semarang was implemented on plan marketing through 4P strategy: product, place, price, and promotion, which is in line with the theory of plan development and marketing program by Belch dan Belch [13].

Product strategy was done from all sides, from packaging, variety, completeness, and quality to available quantity. All informants claimed to be satisfied with the products offered because they varied, were innovative, packaged uniquely, and had good durability. Superior products that have become typical souvenirs from Semarang were also completely available. One of the strategies done was producing several of the superior products by themselves, in order to lower the cost for more affordable selling price, even though the owner had to build own brand by emphasizing on its product excellence.

In terms of place strategy, it has been done ever since the owner built Kampoeng Semarang: a complete and big souvenirs center that provides large area, many attractive spots, and large capacity for its consumers. Certainly, strategic location has become one of the reasons why consumers chose Kampoeng Semarang among other souvenirs places, though the location is on the outskirts of Semarang and sometimes experienced flooding.

For price strategy, all five informants explained that in the world of business, price is the most important factor for someone when decides to make a purchase. The price provided in this business area was very competitive and relatively cheap when compared to similar businesses, as proven by the partner who compared it with the price of souvenirs business in other cities.

Promotion as the last strategy was already experienced by partners, however not to the consumers directly. For this, the owner can do personal promotion to partners and consumers directly, prioritize promotion maximized with good service, which eventually will lead to word of mouth promotion. Digital promotion needs to be improved even more by highlighting uploaded posts that promote business spots that sell and for other promotions. One of the informants even suggested that businesses can provide signs from the city center in order to guide consumers outside the city to come to Kampoeng Semarang.

For the data on brand development process, it was found that market dynamics had moved in tune with tourism progress. People nowadays are more concerned with recreation, although their purchase decision when in the owner's business was adjusted to economic conditions. Market competition also determined how Kampoeng Semarang could continue its journey as consumers' choice. According to the owner who had conducted field observation to understand the competitors, the owner's business competitors did not comply with the use of term "souvenir center" because most of the products offered were mostly souvenir shops. Furthermore, the owner admitted that the strongest competitor for the business was the famously known Pandanaran sector. Even so, the owner saw that this competitor only favored one product, where consumers would find it difficult when they wanted to look for other kinds of typical souvenirs from Semarang. In dealing with competitors, the main components that must be considered by the owner are best price and quality for consumers.

Understanding consumers can be done by seeing the review after purchase is made. Consumers with different characteristics certainly need to get different services. When consumers in a large party namely tour and travel already recognize the owner's business and make regular visits, it can be said as having brand recall stage, although in terms of family is still in brand recognition stage. Therefore, the owner had to be able to understand his or her weaknesses in their intent circle and make strategies in the appropriate strategy circle as Hermawan's theory [15] that brand development process is divided into discovery, intent and strategy circle.

There are several weaknesses identified in this research, such as the business is relatively new, located in the outskirts of Semarang, and not free from flood. Regarding those, the owner has got a solution in form of the government's commitment to renovate the area continuously, although access to the location is still difficult. Another strategy undertaken by the owner was to instill brand soul as a 
souvenirs center while still carry the concept of one stop leisure as conveyed by selling ideas that emphasize the completeness and variety of products offered in the place.

The effectiveness of IMC can be measured if it has gone well through three levels of problems: technical, semantic, and effectiveness [15]. To deal with technical problem, the owner must train the assigned marketing staff for product knowledge, briefings and meetings about service and performance to make sure that marketing staff also have good understanding of the business. To deal with semantic matter, the owner can equip marketing staff with complete information from brochure to cooperation affairs to the partner, such as tour and travel agents, hotels, rentals, and sometimes sharing fee and provision of facilities. Such information can be given in printed form and persuasive offers through electronic media. In terms of tourism marketing, the cooperation made must have benefits for both parties. Finally, effectiveness problem can be easily seen from consumers' reviews who come to the business location and make purchase.

\section{B. The Implementation of Marketing Communication Mix}

Efforts done to reach an effective IMC stage must be balanced with the use of marketing communication mix as a means of positioning the brand in order to be uniquely different for the consumers, as revealed by Chitty et al [16]. The advertising elements were already in printed and online media, and even found several times played on the radio too. Research results showed that digital marketing communication turned out to be very important in this age and therefore must be maintained. The owner has already understood about this, thus dominating the use of Instagram since this social media is the most consumer-interactive media. In addition to that, the company needs to pay attention to point-of-purchase when consumers come to the location. Billboards displayed in front of the location already explain the name of business booths and their products. The location also provided television that displays visual information for all products.

According to two consumers as informants, products arrangement and allocation were the most important factors in determining purchase. The ease of choosing a product was a convenience for consumers. Convincing consumers and partners were done through direct marketing, a fast service in meeting consumers' demand, providing facilities, and communicating directly with partners. Furthermore, sales in the owners' business area did not really involve personal selling because this method was considered as ineffective, since it was delivery service using certain applications. Even so, Kampoeng Semarang has successfully proven its existence, making this business area often has gotten attention from printed media and online media known as MPR. Initially, MPR only highlighted the owner's bag business. Later the attention was given to all products and facilities provided in the area. For other informant, MPR is one of the means to improve the brand. For this, the informant argued that if the brand becomes viral, it can become adding value to the brand. Sales promotion is helpful to maintain visitors. Sales promotion girls or SPG can be placed at a certain point, and the number can be increased during high season to reach all consumers. Although most of the time consumers act as they are uninterested, if SPG actively offers a tester and acts persuasively, they can feel more valued and respected, leading to purchasing the product. In addition to that, the SPG service must stay friendly and helpful for consumers in all kinds of situation.

The final element is marketing sponsorship, which is one way to promote the company by linking the company to certain events. This was not intensely done by the owner, since the owner's business is focused more on tour and travel business. Still, marketing sponsorship has ever been done in form of government program and business catalogs. For the informants, marketing sponsorship is similar with the use of MPR which can be used as a support for brand recognition only. The implementation of marketing communication mix was felt effective enough since this was already in line with its marketing strategies and process. This is also in accordance with the results from Chitty et al [16], explain that the effectiveness of IMC depends on understanding brand marketing environment and integration of various communication media that can influence consumers' purchase decision effectively. This is also supported by Andretti [17] who states that the use of digital and non-digital communications has effects on marketing.

\section{The Implementation of Tourism Communication in the $I M C$}

When a business of certain industry has successfully mastered its performance, there will be wide opportunities to expand business in other industries. In this research, Kampoeng Semarang's focus is tourism, yet the owner also expands the business to producing various foods with expectation that this business can develop. Based on the data from partners and consumers, when people travel, the first thing they remember is souvenirs. This means that Kampoeng Semarang has chosen a business that suits the industry demand in it. Because the tourism industry continues to develop, marketing and communication forms in tourism industry namely the industrial sector, type of client, and type of communication [18] must be considered since they are the benchmarks of customer satisfaction. Kampoeng Semarang has been able to read consumer demand well where consumers are more interested in the typical Semarang products that are commonly purchased and try new products. Always responding dynamically to changing consumer needs and developing products will have an impact on the tourism marketing environment [19] so that consumer satisfaction must also be prioritized because it determines the image going forward [20]. The long-term relationship established by Kampoeng Semarang is by providing good services. For partners, Kampoeng Semarang is always actively communicating, organizing sharing and gathering. Kampoeng Semarang prioritizes service and product quality for customers on a regular basis, but this is still felt lacking, where one informant suggested that businesses can give gifts or members as a reminder to be able to visit Kampoeng Semarang again.

The interesting thing is that despite the weaknesses and shortcomings of the owner's business, in the end according to the results of data analysis, all informants agreed that Kampoeng Semarang had done a pretty good, structured and proper IMC. This has a positive impact on consumer purchases and customer satisfaction which results in ongoing purchases and promotions to others indirectly. That is, the business owner has a clear understanding of what the market wants, and meets these needs. Products and services have also 
been delivered at the right time, quantity, packaging and place as explained by Walsh [20] that in tourism marketing, marketers must pay attention to these matters. It is also in accordance with the findings of Yurdakul and Bozdag [21] that the application of integrated marketing communication needs to adjust the communication strategy undertaken, understand strengths and weaknesses, follow developments such as conducting creative marketing through cellular applications, and invest in traditional and digital media.

\section{CONCLUSIONS}

The integrated marketing communication of Kampoeng Semarang can be seen in the image below:

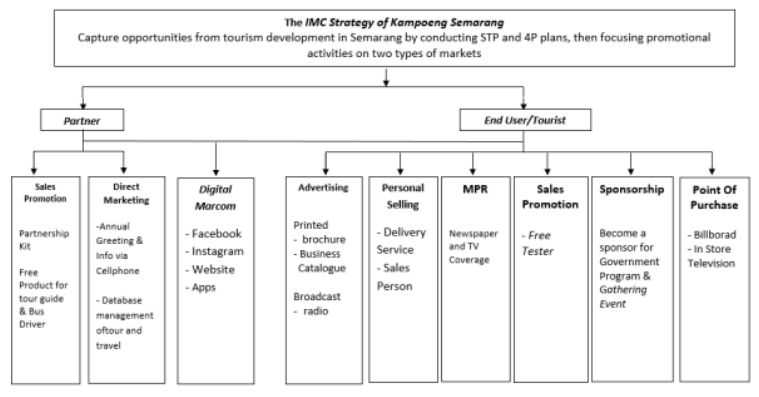

Fig. 2. The IMC of Kampoeng Semarang

Determination of the IMC begins with capturing opportunities, where tourism in Semarang is in a developing condition. The company then determines the market segments (S) and targets $(\mathrm{T})$ and makes a positioning $(\mathrm{P})$, or better known as the STP process. Then determined the marketing strategy that includes products, prices, places, and promotions, or better known as 4P. Specifically the promotion conducted by Kampoeng Semarang focuses on two target markets, namely partners and end users or tourists. The type of promotion carried out is tailored to the needs of each target market. For partners the emphasis is on providing added value if they bring consumers to Kampoeng Semarang, and establish good relations through sales promotion and direct marketing activities. As for direct consumers, promotional activities are more varied to gain awareness and encourage their purchases. There is one type of promotion given to partners and end users, namely digital marketing communication. This activity is carried out considering the two types of targets can be reached with it.

\section{REFERENCES}

[1] Indonesia Investment, "Industri Pariwisata Indonesia," 16 Desember 2016. [Online]. Available: https://www.indonesiainvestments.com/id/bisnis/industri-sektor/pariwisata/item6051?

[2] A. Ibo, "Sektor Pariwisata Jadi Investasi Unggulan di 2018," 7 Januari $2018 . \quad$ [Online]. Available: https://www.liputan6.com/lifestyle/read/3217850/sektor-pariwisatajadi-investasi-unggulan-di-2018.
[3] A. Ibo, "Jalan Pandanaran, Surga Belanja Oleh-oleh Khas Semarang," 2018. [Online]. Available: https://www.indonesiakaya.com/jelajah indonesia/detail/jalan-pandanaran-surga-belanja-oleh-oleh-khassemarang. [Accessed 21 September 2018].

[4] J. Setyanto, "Kampoeng Semarang, Destinasi Wisata Baru di Semarang," 24 November 2013. [Online]. Available: http://potensijateng.com/newface/kampoeng-semarang-destinasiwisata-baru-di-semarang/.

[5] Kampoeng Semarang, "Tentang Kami," 20 September 2018 [Online]. Available: https://kampoengsemarang.com/kampoengsemarang. [Accessed 20 September 2018].

[6] Seputar Semarang, "Kampoeng Semarang, Pusat Oleh-oleh dan Souvenir," $2012 . \quad$ [Online]. Available: http://seputarsemarang.com/kampoeng-semarang-pusat-oleh-olehdan-souvenir/.

[7] H. Herdiansyah, Metodologi Penelitian Kualitatif untuk Ilmu-ilmu sosial, Jakarta: Salemba Humanika, 2012.

[8] B. Bungin, Metodologi Penelitian Sosial dan Ekonomi : Format format Kuantitatif dan Kualitatif untuk Studi Sosiologi, Kebijakan Publik, Komunikasi, Manajemen, dan Pemasaran, Jakarta: Prenadamedia Group, 2015

[9] H. Herdiansyah, Metode Penelitian Kualitatif, Seni dalam Memahami Fenomena Sosial, Yogyakarta: Greentea Publishing, 2009.

[10] I. Gunawan, Metode Penelitian Kualitatif : Teori dan Praktik, Jakarta: Bumi Aksara, 2016.

[11] M. Nazir, Metode Penelitian, Bogor: Ghalia Indonesia, 2014.

[12] B. Caemmere, "The planning and implementation of integrated marketing communications," Marketing Intelligence \& Planning Vol. 27 No. 4, pp. 524-538, 2009.

[13] G. Belch and M. Belch, Advertising and Promotion: An Integrated Marketing Communication Perspective, Eigth Edition, New York: McGraw-Hill, 2009.

[14] R. Rismayanti, "Integrated Marketing Communications (IMC) di PT Halo Rumah Bernyanyi," Jurnal Ilmu Komunikasi, Volume 13 Nomor 2, pp. 253-266, 2016.

[15] A. Hermawan, Komunikasi Pemasaran, Jakarta: Penerbit Erlangga, 2012

[16] B. Chitty, E. Luck, N. Barker and et.al, Integrated Marketing Communications, Australia: Cengage Learning, 2012.

[17] Y. R. Andretti, "Intregrated Marketing Communication dalam Komunikasi Pemasaran PT. DBL Indonesia," Jurnal Komunikasi, pp. 1-14, 2016.

[18] I. G. B. Rai Utama, Pemasaran Pariwisata, Yogyakarta: Andi, 2017.

[19] S. McCabe, Marketing Communication in Tourism and Hospitality : Concepts, Strategies, and Cases, Oxford: Elsevier, 2009.

[20] T. Walsh, Tourism Promotion, New Delhi: Tilak Wasan, 2011

[21] E. Yurdakul and A. Bozdag, "IMC: Integrated Marketing Communications," Marketing Management, pp. 275-297, 2018.

[22] Dinas Kepemudaan Olah Raga dan Pariwisata Provinsi Jawa Tengah, "Statistik Pariwisata Jawa Tengah 2015," 2016. [Online]. Available: http://disporapar.jatengprov.go.id/content/files/Statistik\%20Pariwisa ta\%20Jawa\%20Tengah\%202015.pdf. [Accessed 10 October 2019]. 